AGRICULTURE AND BIOLOGY JOURNAL OF NORTH AMERICA

ISSN Print: 2151-7517, ISSN Online: 2151-7525, doi:10.5251/abjna.2013.4.4.441.458

(C) 2013, ScienceHuß, http://www.scihub.org/ABJNA

\title{
Farm Level Analysis of Investment Behaviours in Soil Conservation and Erosion Control Practices in the Ecologically Vulnerable Communities in Southeast Nigeria \\ Donatus Orji, Onu.
}

\author{
Department of Agricultural Economics and Extension, \\ Ebonyi State University, P. M. B 53, Abakaliki, Nigeria \\ Email: drdonatusonu@yahoo.com \\ drdanatusonu@gmail.com
}

\begin{abstract}
This study analyzed the determinants of farm-level soil conservation investment behaviours in Southeast Nigeria. A probit econometric model was used to analyze data obtained from 480 randomly selected farm households from 12 erosion-prone communities in the region. The results show that younger farmers aged between 18-44 years cultivating at least 0.7 ha of land over which they have control in terms of allocation and usage had higher probabilities of investing in the conservation practices compared to the older farmers. Investment decisions increased with increased farm households' own liquidity, off-farm income, knowledge of the practices through extension contacts, level of formal education, ownership and control over cultivated lands, length of land lease, membership in farmers' associations, and farm sizes greater than the mean farm size of 0.7 ha. But insecurity of land tenure generally increased farmers' risk of appropriation of input resources and decreased investments in the practices, especially for the female farmers who do not have title to land in the area. Investments in the practices also decreased with increased family sizes and the erosion-induced land scarcity conditions in the region. The study confirms the importance of recognizing the heterogeneity of the farming population not only in terms of the biophysical conditions of their farms but also the socioeconomic and demographic conditions under which they operate. Extension efforts in Southeast Nigeria should therefore target the younger farmers and promote projects aimed at developing off- farm enterprises, since these positively influence household liquidity and investments in conservation practices.
\end{abstract}

Keywords: Soil Conservation, Erosion Control, Investment Behaviours, Farm-level, Southeast Nigeria

\section{INTRODUCTION}

Increasing food production to keep pace with demand while retaining the quality of land and the ecological balance of the production systems are the current challenges to agricultural research and development policy in Nigeria. Currently, efforts to achieve sustainable agricultural development and food selfsufficiency in the country are threatened by widespread environmental degradation resulting from soil erosion menace, characterized by massive soil loss estimated at 30 million tons per annum(Onu,2006; Igbokwe,2004;Lal,2001).

The situation is particularly pronounced in the ecologically vulnerable areas of Southeast Nigeria, where the population densities and least land per capita rank among the highest in rural Africa (Onu, 2006; Eboh and Lemchi, 1994). More than 50 percent of the estimated 30 million tons annual soil loss in Nigeria through erosion is obtained in this region (Onu, 2006; Obiefuna and Emebiri, 1996). The average soil loss is currently estimated at between 158.8 and 500 tons/ha/year, and about 70 percent of the total land area of the region are affected by different and varying degrees of erosion menace; ranging from mild sheet wash to deep gullying (Junge, et.al; 2008; Egboka, 2004; Obiefuna and Emebiri, 1996); when ordinarily erosion rates in the region that exceed 10 to 30 tons/ha/year are considered problematic (Igbokwe, 2004; Obiefuna and Emebiri, 1996).

The massive soil loss in the Southeast Nigeria results in severe ecological damages, soil fertility depletion, loss of soil structure, reduction of soil biodiversity, soil compaction, decline in agricultural productivity, low 
farm income, poverty, food insecurity and social disorder (Junge, et.al; 2008; Lal, 2001; Eswaram, et al; 2001).

Both physical, socioeconomic and anthropogenic factors as well as deficient agricultural production practices are believed to have aggravated and exacerbated the high erodibility of the soils in the region. Steep slopes, highly variable and erosive rains, changing seasonalities, deforestation, devegetation, intensified cultivation linked to the high demographic pressures, gender and social inequalities, poverty and soil misuse were the specific culprit factors identified to have raised and aggravated the ecological vulnerability and food insecurity situations in the Southeast region of Nigeria (Junge, et.al; 2008; Eboh and Lemchi, 1994; Mbagwu, 1984).

Like in many other ecologically vulnerable areas of Africa, Asia and America, the problem of land degradation has, for Nigeria, become a matter of national, regional and State concern. The foci of the Nigerian's national and Southeast regional strategy to control erosion menace and restore soil productivity is the promotion of soil conservation extension programmes aimed at accelerating farm level adoption and investments in the use and application of soil conservation and erosion control innovations, notably mulching, use of cover crops, alley cropping, anti-erosion ditches, radical terraces and others.

Variants of these technology packages are being introduced to farmers for adoption and applications on continuing basis in Southeast Nigeria by the State Ministries of Agriculture, Environment and the World Bank-assisted Agricultural Development Projects (ADPs) with huge support from several International Donor agencies since the early 1990s. While the potential constraints to the adoptability and investment in the conservation and erosion control technology packages have been identified by some Researchers to include scarcity and high costs of the technology materials, long gestation period between the establishment and accrual of benefits, complexity of the technology packages and inappropriate land use regimes (Dvorak, 1996; Cater, 1995; Smucker, et.al; 1995; Tonye, et.al; 1993; Kayombo and Lal, 1993) (see table 6, 7,8 and 9); socioeconomic studies of the determinants of the farmers' actual adoption and investment in the technology packages are generally limited in Nigeria and completely lacking in the Southeast region. The existence of this gap in knowledge creates difficulties in the modification and reformulation of the soil conservation and erosion control policies and programmes for the extension efforts to optimize their impacts and ensure increased adoption rates and greater investments in the recommended conservation and erosion control practices by the potential farmer adopter categories. But, the evaluation of the key to success of several similar projects implemented in Central and South America show that it has been due to the availability of data on what determines the farmers' investment behaviours which enhanced continuous modifications of the conservation policies and packages, and its' re-introduction to the farming systems using extension delivery methods that are in consonance with the farmers' social, economic, environmental and agronomic circumstances (Hansen, et.al; 1987; Napier, et.al; 1984). Unfortunately, the American circumstances and prescriptions do not have universal application to other regions of the World, because soil degradation is a biophysical process and are location specific, and are usually determined by the existing and prevalent social, economic and biophysical factors (Lal, 2008; Junge, et.al; 2008).

Economic theory was also not specific over the phenomena, but suggests conflicting hypotheses with respect to the determinants of farm-level soil conservation innovation adoption and investment behaviours, especially in a rural context like Southeast Nigeria ( Onu, 2005 ). On the one hand, it has been suggested that with a declining land base due to soil erosion and weak credit market to insulate the households from land shortages, households would be compelled to husband carefully their declining resource base through conservation investments (Ehui et al, 1992). On the other hand, Newbery and Stiglitz (1981) suggest that the risk resulting from price and rainfall instability or from insecurity of the land tenure (risk of appropriation of capital) is inimical to investments in soil conservation for risk averse farmers. Rather than narrowly focusing on their land base, farmers diversify their asset portfolios and incomes through off-farm employments (Robinson and Barry, 1987; Binswanger, 1986). Yet both from theory and empirical evidence for farm asset investment, offfarm income as a liquidity source could be critical to on-farm investments where there is failure of, or constraints in the credit market.

It is therefore clear from theory that there can be competing forces encouraging and discouraging farm households from investing in soil conservation and erosion control measures. In an attempt to fill this gap in knowledge, this study identified and quantified 
factors that determines farmers' investment behaviours in the recommended soil conservation and erosion control practices in the Southeast agroecological region of Nigeria; using multivariate discrete choice probit model. The model assumes that farmers' investment behaviours in the recommended conservation practices are a function of financial and physical incentives/disincentives to invest, riskiness of investment, capacity to invest( human and physical capital, liquidity sources),and other household characteristics.

Soil conservation and erosion control practices developed by research and recommended to farmers in Southeast Nigeria and the specific practices examined by this Study: Research and recommendations in soil conservation and erosion control innovations have been done for many years in Nigeria (e.g, Fournier, 1967; Lal, 1976; Greenland and Lal, 1977; Lal, 1990; Kayombo and Mrema, 1998; Ehrenstein, 2002; Ehui and Ponder, 2005), and in the Southeast region (e.g. Mbagwu, et.al, 1984; Igwe, 1999 and 2003; Igbokwe, 2004). These and other initiatives have resulted in the development and recommendation of several on-farm conservation methods in the Southeast region of Nigeria, which are summarized and classified by this study into agronomic soil conservation strategies, soil management strategies and mechanical methods as depicted in figure 1.

This study concentrated and evaluated the determinants of farm level investment behaviours in three agronomic soil conservation and erosion control practices namely mulching, cover crops and alley cropping (multiple cropping) that have universal application in the erosion-prone communities of Southeast region of Nigeria. They are biological measures and are effective in reducing risks of water run-off and soil erosion, improving soil quality by enhancing soil organic matter reserves, strengthening nutrient recycling mechanisms, and increasing activity and species diversity of soil fauna (e.g. earthworms, termites, micro-organisms, etc) (refer to appendixes 1,2 and 3 for details).They are briefly described here as follows:
Mulch is a layer of dissimilar materials placed between the soil surface and the atmosphere. Different types of materials such as residues from the previous crops, brought-in mulch, including grasses, perennial shrubs, farmyard manure, compost, byproducts of agro-based industries, or organic materials are used as mulch. Synthetic products can also be used for mulching (Lal, 1990). The impact of mulch in reducing splash effect of rain, decreasing the velocity of runoff, reduction of soil loss and improving soil fertility and agricultural productivity has been demonstrated in many field experiments conducted on several Nigerian research stations by several Researchers (see appendix 1 for details)

Cover crops such as the legumes: $P$. phascoloides, M. pruriens, Centrosema pubescens, Stylosanthes guianensis, and Phaseolus aconitifobius or the grasses: Pennisetium purpureum, Brachiaria niziziensis, and Paspalum notatum are plants that grow rapidly and close (Lal; 1995). Their dense canopy prevents rain drops from detaching soil particles, and this keeps soil loss to tolerable limits, conserves the soil and improves soil fertility and productivity as demonstrated by many field experiments and research results in Nigeria (see appendix 2 for details).

Alley cropping is an agroforestry technique involving the cultivation of food crops between nitrogen fixing leguminuous hedgerow species (Leucaena lecucocephala and Gliricidia sepium) (Kang, et.al; 1990), developed at the International Institute of Tropical Agriculture, Ibadan, Nigeria in the 1980s. The leguminous species have deep roots for nutrient capture and recycling, produce substantial biomass, which are applied to crops as mulch, and contribute to nitrogen fixation. The technology requires farmers to periodically prune the leaves of the hedgerow trees or shrubs for application as mulch. The technology has been shown to increase and sustain crop production compared to conventional bush fallow, prevent soil erosion, control weeds, enhance nutrient recycling, and build up soil organic matter under the most intensely cultivated and continuously cropping systems (Kang, et al, 1990; Lal, 1983) (see appendix 3 for details). 


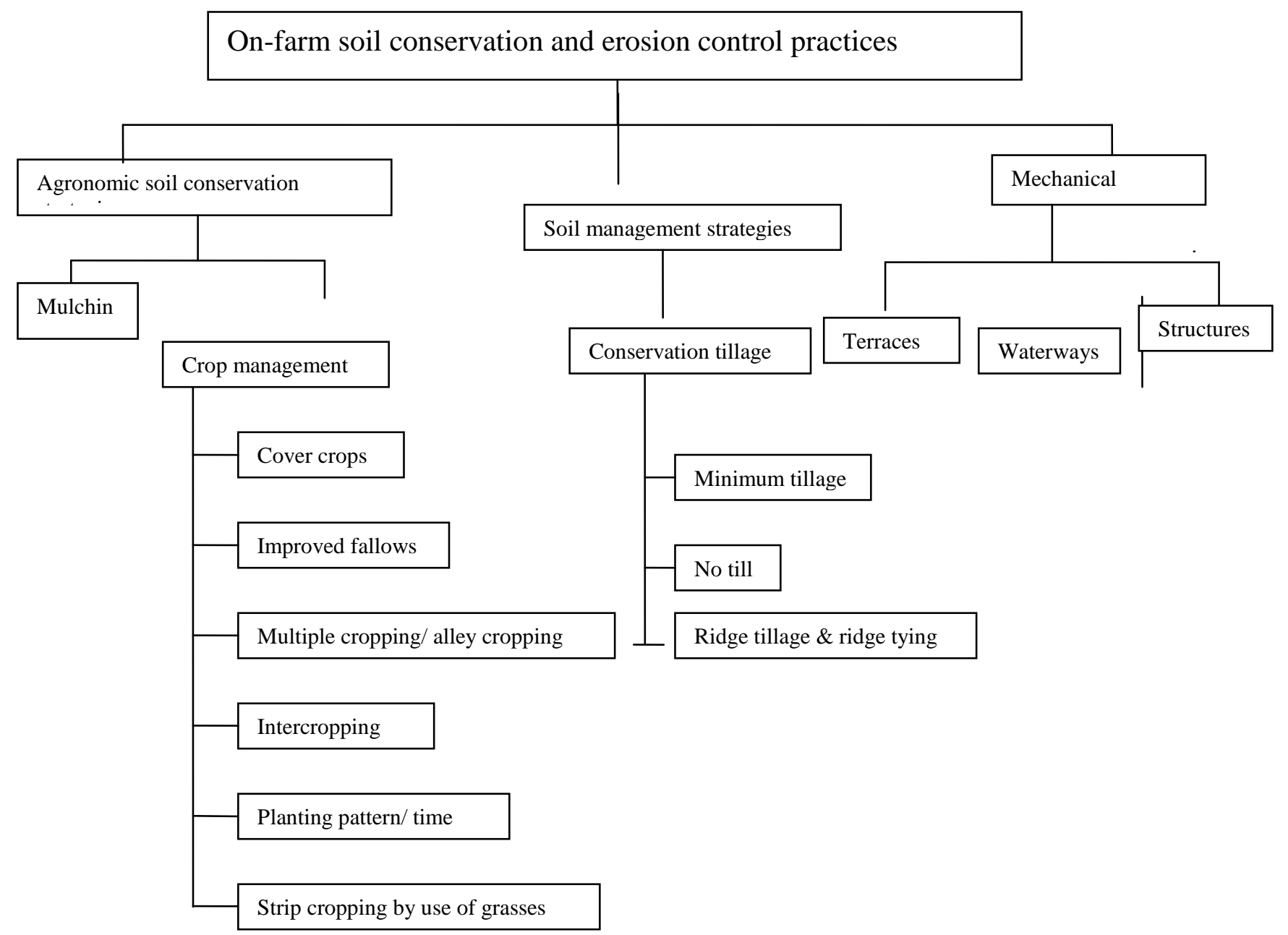

Fig 1: On- farm erosion control strategies ( Adapted from Junge, et al; 2008 )

\section{MATERIALS AND METHODS}

Data Collection: Data used for this study were collected through oral and farm level survey of 480 randomly selected farmers from 12 erosion-prone communities in the Southeast region of Nigeria. The communities studied are Agulu Nanka, Awka, Amucha, Okwudor, Arochukwu, Ukpor, Igbere, Udi, Obolo Afor, Afikpo, Isuikwuato, and Uwana. These communities were purposively selected because they represent areas where the intensity and scope of erosion hazards rank among the highest in the Southeast Nigeria; and where farmers' fields are affected by varying degrees of erosion menace as documented by earlier studies: Onu, 2006 and 2005; Egboka, 2004 and Obiefuna and Emebiri, 1996. Soil conservation and erosion control extension education/ service activities are being conducted on continuing basis by the Research and Development workers of the States' Ministries of Agriculture and Natural Resources and the States' World Bank assisted Agricultural Development Projects in these twelve communities.

The respondents were randomly selected from the list of farmers (both investors and non- investors) provided by the resident Agricultural Extension agents using random numbers. The sample therefore included both investors and non-investing farmers. Farmers who have started applying mulch, cover crops and or growing their crops in alleys between hedgerows of leguminous trees are regarded in this study as investors, while non- investing farmers are those that have not.

Structured and validated interview schedules and field enumerators conversant with the local dialects 
and customs of these communities were used to collect data from the respondents. The survey covered information on farmers' knowledge, adoption and investment in the conservation and erosion control innovations, family size, farm income, nonfarm income, level of formal education of farm household head, land ownership statues, age of farm household head, length of land lease, gender, contact with soil conservation extension agents and farmers' participation in their community social organizations. The physical features of individual farm household fields including farm sizes, location on slope, distance from residence, erosivity of the land use, share of the operational holdings under fallow and slope were practically measured by the enumerators together with the respondents under the supervision of the Researcher. The survey and data collection lasted between June 2012 and March 2013.

\section{Analytical Framework and Model for Empirical Analysis of Data: Descriptive statistics including mean scores, percentages, coefficients of variation and one-way analysis of variance were used in analysing the socioeconomic and agronomic features of the respondents; while multivariate probit technique was used to analyze the determinants of farm-level investment behaviours in soil conservation and erosion control practices.}

The multivariate probit model simultaneously modelled the influence of a set of explanatory variables(independent variables) on each of the soil conservation and erosion control measures(dependent variables), while allowing the unobserved and unmeasured factors (error terms) to be freely correlated (Lin, et.al; 2005; Golob and Regan, 2002). Complementarities (positive correlations) and substitutabilities (negative correlations) between different conservation options were suspected to constitute sources of correlations between error terms (Belderbos, et.al; 2004). Another source of possible positive correlation is the existence of unobservable household-specific factors that affect choice of several conservation and erosion control options but are not easily measurable such as indigenous knowledge. These correlations were taken into account in the multivariate probit model.

Following Lin, et.al. (2005), the multivariate probit econometric approach that was used for this study is characterized by a set of $n$ discrete dependent variables $y_{i}$ (with observation subscripts suppressed), such that:

$$
\begin{aligned}
& Y_{1}=1 \text { if } x^{\prime} \beta_{i}+\varepsilon_{1}>0, \\
& =0 \text { if } x^{\prime} \beta_{i}+\varepsilon_{1} \leq 0, i=1,2, \ldots, n,
\end{aligned}
$$

where $\mathrm{x}$ is a vector of explanatory variables, $\beta_{1}$, $\beta_{2}, \ldots \ldots \beta_{\mathrm{n}}$ are conformable parameter vectors, and random error terms, $\varepsilon_{1}, \varepsilon_{2} \ldots \ldots, \varepsilon_{n}$ are distributed as multivariate normal distribution with zero means, unitary variance and an $n \times n$ contemporaneous correlation matrix $R=\left[p_{i j}\right]$, with density

$\phi\left(\varepsilon_{1}, \varepsilon_{2}, \ldots, \varepsilon_{n} ; R\right)$. The likelihood contribution for an observation is the n-variate standard normal probability

$\operatorname{Pr}\left(y_{1, \ldots, \ldots} y_{2} \mathrm{o} \quad \mathrm{x}=\int_{\infty}^{\left(2 y_{1}-1\right) x^{\prime} \beta_{1}} \int_{\infty}^{\left(2 y_{2}-1\right) x^{\prime} \beta_{2}} \ldots \mathrm{X} \int^{\left(2 y_{n}-1\right) x^{\prime} \beta_{\mathrm{n}}} \phi\left(\varepsilon_{1}, \varepsilon_{2}, \ldots, \varepsilon_{\mathrm{n}} ; Z \mathrm{R} Z\right) \mathrm{d} \varepsilon_{n} \ldots \mathrm{d} \varepsilon_{2} \mathrm{~d} \varepsilon_{1}\right.$,

where $Z=\operatorname{diag}\left[2 y_{1}-1, \ldots, 2 y_{n}-1\right]$. The maximum likelihood estimation maximizes the sample likelihood function, which is a product of probabilities (2) across sample observations. Computation of the maximum likelihood function using multivariate normal distribution requires multidimensional integration, and a number of simulation methods were put forward to approximate such a function with the GewekeHajivassiliou-Keane (GHK) simulator being widely used (Belderbos, et.al., 2004). This study followed the GHK simulator approach and used the STATA routines based on Cappellari and Jenkins (2003) to estimate the model.

The marginal effects of the explanatory variables on the propensity to invest in each of the different conservation measures were calculated as: $\partial P_{i} \mid \partial x_{i}=\phi\left(x^{\prime} \beta\right) \beta_{i}, i=1,2, \ldots, n$. Where $P_{i}$ was the probability (or likelihood) of the event $i$ (that is, increased application of each conservation measure), $\phi($.) was the standard univariate normal cumulative density distribution function, $x$ and $\beta$ were vectors of regressors and model parameters respectively (Hassan, 1996).

Econometric analysis with large sectional data and sample size like in this study (480 respondents) is usually associated with problems of heteroskedasticity and multicollinearity and the effect of outliers in the variables. Multicollinearity among explanatory variables can lead to imprecise parameter estimates. To explore potential Multicollinearity among the explanatory variables, the Variance Inflation Factor (V1F) for each of the explanatory variables were calculated. It was accepted when the calculated VIFs range did not 
reach convectional thresholds of 10 or higher used in regression diagnosis (Lin, et.al. 2005). In the analysis, Multicollinearity did not appear to be a problem. To address the possibilities of heteroskedasticity in the model, a robust model that computes a robust variance estimator based on a variable list of equation-level scores and a covariance matrix was estimated.
Table1 defines and explains how the variables were measured, while tables 2 and 3 show the sample statistics of the variables measured and used in the multivariate discrete probit analysis; while table 5 shows the results of the multivariate probit estimates of the determinants of farm-level investment behaviours in soil conservation and erosion control practices in Southeast Nigeria.

Table 1: Definition and measurement of variables used in the multivariate probit model

\begin{tabular}{|c|c|c|}
\hline Variables: & Unit/Type & Description \\
\hline $\begin{array}{l}\text { (A) Dependent variables: } \\
\text { Investments in soil conservation } \\
\text { and erosion control practices }\end{array}$ & $\begin{array}{l}\text { Meter } \\
\text { hectare }\end{array}$ & $\begin{array}{l}\text { Proportion of total farm land area (number of plots } x \text { size) to which a } \\
\text { farmer has applied conservation treatment relative to his/her total } \\
\text { farm land holdings. }\end{array}$ \\
\hline \multicolumn{3}{|l|}{$\begin{array}{l}\text { (B) Independent (Explanatory) } \\
\text { variables: }\end{array}$} \\
\hline Farm income & Binary & $\begin{array}{l}\text { 1, if farm income (in naira) exceeds sample mean of } \$ 67,000.0 \\
\text { otherwise. }\end{array}$ \\
\hline Non- farm Income & Binary & $\begin{array}{l}\text { 1, if farm household earns income from other sources different from } \\
\text { farming; } 0 \text { otherwise. }\end{array}$ \\
\hline Erosivity of land use & $\begin{array}{l}\text { C- value } \\
\text { index }\end{array}$ & $\begin{array}{l}\text { The ratio of soil loss from an area with specific cover and tillage } \\
\text { practice to that from an identical area in tilled continuous fallow } \\
\text { (Wischmeier and Smithy, 1978). This represents the average soil } \\
\text { loss ratio resulting from crop cover, canopy and tillage practices } \\
\text { which varied throughout the growing (production) season during the } \\
\text { period of the study. }\end{array}$ \\
\hline Slope of the land & Degrees & $\begin{array}{l}\text { The angle of elevation or depression in a topographic sequence } \\
\text { where a farm field is located. }\end{array}$ \\
\hline $\begin{array}{l}\text { Toposequence location of farm } \\
\text { field }\end{array}$ & Binary & Location on slope: 1 high; 0 low \\
\hline Land under fallow & $\begin{array}{l}\text { Meter per } \\
\text { hectare }\end{array}$ & Proportion of total farm land area under fallow. \\
\hline Farm size & Hectare $(\mathrm{Ha})$ & $\begin{array}{l}\text { Total number of farm fields } \times \text { size. } 1 \text {, if household farm size exceeds } \\
\text { the sample average of } 0.70 \text { ha; } 0 \text { otherwise. }\end{array}$ \\
\hline Distance of farm from residence & Minutes & $\begin{array}{l}\text { Length of time in minutes it takes a farmer from his/her residence to } \\
\text { the farm field. }\end{array}$ \\
\hline Land ownership right & Binary & $\begin{array}{l}1 \text {, if farm household owns and controls allocation of cultivated land; } \\
0 \text { otherwise. }\end{array}$ \\
\hline Length of land lease & Years & Number of years a farmer uses rented farm land. \\
\hline Farm households' access to credit & Index & $\mathrm{O}=$ unavailable to $5=$ regular use \\
\hline Age of farm household head & Years & $\begin{array}{l}\text { 1, if age of farm household head exceeds sample mean of } 44 \text { years; } \\
\text { O otherwise. }\end{array}$ \\
\hline $\begin{array}{l}\text { Level of formal education of farm } \\
\text { household head }\end{array}$ & Years & $\begin{array}{l}\text { Number of years of formal education attained by farm household } \\
\text { head. }\end{array}$ \\
\hline Family size & Number & $\begin{array}{l}\text { Total number of people in a household, excluding adult age children } \\
\text { not living at home. } 1 \text {, if family size exceeds the sample average of } \\
9 ; 0 \text { otherwise. }\end{array}$ \\
\hline $\begin{array}{l}\text { Membership and participation in } \\
\text { community and farmers' } \\
\text { organizations }\end{array}$ & Binary & $\begin{array}{l}1 \text {, if the household head is a member and participates in his } \\
\text { community/ farmers' association; } 0 \text { otherwise. }\end{array}$ \\
\hline $\begin{array}{l}\text { Contacts with soil conservation } \\
\text { extension agents }\end{array}$ & Binary & $\begin{array}{l}\text { 1, if farm household head benefits from extension agents contacts; } \\
0 \text { otherwise. }\end{array}$ \\
\hline Gender & Binary & 1, if household head is a male; 0 otherwise. \\
\hline
\end{tabular}




\section{RESULTS AND DISCUSSION}

Socioeconomic and biophysical features of the sample farm household respondents: Table 2 shows that majority of the farmers are smallholders, cultivating an average farm size of 0.7 hectare of land, scattered at different locations. Majority of the land holdings are owner- operated; while the length of land lease is 1.20 years. The length of land lease suggests uncertainty over continued use of rented lands, as it may result to shortened planning horizon for renters. The practices of year- to - year leases by oral agreement attests to this uncertainty. In practices, many land renters in the sampled communities in Southeast Nigeria operate their rented lands for very limited period ( $<1.20$ years) that are insufficient to recover the costs of their investments in most soil conservation and erosion control practices. This situation may have accounted for the observed lack of long- term interest in rented lands by farm households in the sampled communities.

Table 2:
Virtually all arable lands in the sample communities are used for agriculture. Marginal lands once set aside or left in long fallows are coming under more intensive forms of cultivation due mainly to the ever increasing and uncontrolled population pressure, urbanization and erosion menace. Little is kept under fallow (120M/ ha; i.e. 0.12 proportions) (Table 2 ).

Table 2 shows that the sampled farmers' fields tend to be located on erosive hilly topography. The interaction of these biophysical features of the farmers' farm fields with the climate change- induced highly variable and erosive rainfall in the Southeast Nigeria must have been responsible for the high erosivity of the soils in the sampled communities. These prevalent biophysical and climatic conditions in the region highlights and defines the need for soil conservation and erosion control, and provides strong incentive for farmers to take appropriate measures and make investments in controlling their soil loss.

Summary statistics of Independent variables used in the empirical multivariate probit choice model

\begin{tabular}{|l|l|l|l|l|}
\hline Variables & Mean & $\begin{array}{l}\text { Standard } \\
\text { deviation }\end{array}$ & Minimum & Maximum \\
\hline Farm income (A) & 67,200 & 0.37146 & 10,640 & 326,500 \\
\hline Non- farm income (A) & 43,380 & 0.9617 & 0 & 1 \\
\hline Eosivity of land use (C- value index) & 0.62 & 0.14 & 0.12 & 1.20 \\
\hline Slope of land/ farm field (degrees) & 19.62 & 0.82 & 0 & 45.00 \\
\hline Toposequence location of farm field & 0.78 & 0.32 & 0 & 1.00 \\
\hline Proportion of total land area under fallow (M/ha) & 120 & 0.21 & 62 & 220 \\
\hline Farm size (ha) & 0.7032 & 0.5626 & 0.60 & 12.00 \\
\hline Distance of farm field from residence & 13.06 & 3.19 & 2.00 & 120.00 \\
\hline Land ownership right & 0.4429 & 0.7206 & 0 & 1.00 \\
\hline Length of land lease (years) & 1.2040 & 0.5102 & 1 & 5.00 \\
\hline Farm household access to credit & 0.084 & 0.25 & 0 & 5.00 \\
\hline Age of farm household head (years) & 44.38 & 0.34 & 18 & 78 \\
\hline Level of formal education of farm household head & 1.42 & 0.8230 & 0 & 16 \\
\hline Family size & 9.36 & 3.42 & 1 & 18 \\
\hline $\begin{array}{l}\text { Membership and participation in community and } \\
\text { farmers organization }\end{array}$ & 0.7232 & 0.43 & 0 & 1 \\
\hline Contacts with soil conservation extension agents & 0.78 & 0.46 & 0 & 1 \\
\hline Gender & 0.6638 & 0.47 & 0 & 1 \\
\hline
\end{tabular}


Table 2 also shows that rural formal and informal credit markets are severely underdeveloped in Southeast Nigeria generally and in the sampled communities in particular; and these resulted to the farmers' limited access to credit. The table shows that farmers are substituting the lack of formal and informal credits by generating non- farm incomes through employment of their labour for wages in offfarm agricultural and non- agricultural enterprises.

These wages constitute greater proportion of the farm households total income ( $\mathbb{N} 43,380 / \mathbb{N} 67,200$, i.e.; 0.65) (Table 2). This shows that majority of the farm households have switched to risk-minimizing non- agricultural strategies to secure cash incomes through off- farm employments in order to remain food secure even during periods when labour is required on their own farms in case there is failed production due to erosion threat. Onu (2005) noted that the switch to such risk- minimizing nonagricultural production practices in the erosion- prone areas by farmers serve as a coping strategy for income diversification and generation during planting seasons. According to this author, the income generated through such strategies are used for food and farm inputs purchase and payment of hired labour during planting seasons until crops are harvested.
Farmers' knowledge level of the recommended soil conservation and erosion control practices: Table 3 shows that majority $(74.17 \%)$ of the respondents were aware (had knowledge) of the recommended soil conservation and erosion control practices. Only $4.17 \%$ of the sample had never heard of the technologies and may not have appreciated their agronomic advantages and their potentials in erosion control and reduction of soil loss. The table shows that $41.25 \%$ of the sample had started the application of the conservation technologies to their farm fields, while about $18 \%$ were experimenting with the technology packages to properly evaluate it's agronomic and socioeconomic benefits by making contacts with fellow farmers and the soil conservation extension agents. About $16 \%$ of the respondents have discontinued the use of the practices, probably due to problems associated with it's high labour requirements, scarcity of the technologies' component materials, cost of the technology materials, lack of information on proper management of the technologies and complexity of the technology packages as identified by Dvorak (1999), Carter (1995), Smucker, et.al. (1995), Tonye, et.al; (1993) and Kayombo and Lal (1993).

Table 3: Farmers' knowledge of the recommended soil conservation and erosion control practices.

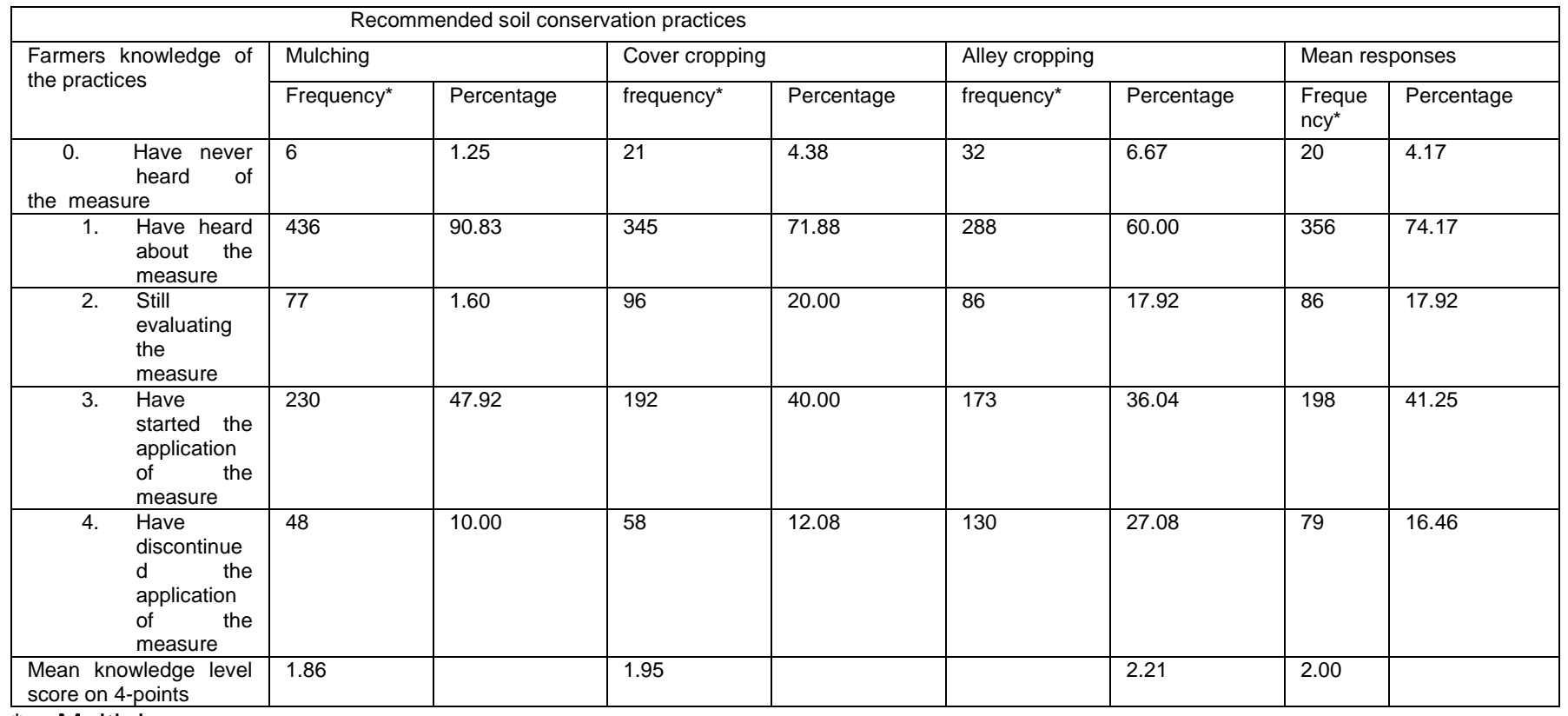

${ }^{*}=$ Multiple responses 
The mean knowledge level score for the respondents over the three recommended soil conservation and erosion control practices evaluated in this study was 2.00 out of a maximum score of 4.00 ; showing that the respondents were aware and have good knowledge of the practices as erosion control and soil conservation technologies.

Farmers' investment behaviours in the recommended soil conservation and erosion control practices: Table 4 shows strong variation among farm households' investment in the three recommended soil conservation and erosion control practices; with mulching and alley cropping receiving highest and lowest investments respectively. There were no significant differences in the mean investments farmers made in their application of mulch and cover crops as soil conservation and erosion control practices; but significant differences existed between farmers' investments in alley cropping and mulching and cover cropping, with alley cropping receiving the least investments.

Table 4: Summary statistics of the dependent variables used in the empirical Multivariate probit choice model

\begin{tabular}{|l|l|l|l|l|}
\hline Variables & Mean & $\begin{array}{l}\text { Standard } \\
\text { deviation }\end{array}$ & Minimum & Maximum \\
\hline $\begin{array}{l}\text { Mulching } \\
\text { (M/ha) }\end{array}$ & $188^{\mathrm{a}}$ & 0.89 & 120 & 600 \\
\hline $\begin{array}{l}\text { Cover } \\
\text { cropping } \\
\text { (M/ha) }\end{array}$ & $178^{\mathrm{a}}$ & 1.80 & 98 & 520 \\
\hline $\begin{array}{l}\text { Alley } \\
\text { cropping } \\
\text { (M/ha) }\end{array}$ & $75^{\mathrm{b}}$ & 2.72 & 42 & 502 \\
\hline
\end{tabular}

${ }^{\mathrm{ab}}$ means within column bearing different superscripts differ significantly $(p<0.05,0.01)$

Table 4 also shows that farmers' investments in the recommended conservation and erosion control practices are generally low despite their wide knowledge of the superiority of the technologies over their traditional practices (Table 3), and their need to conserve their farm land by reducing soil loss (Table 2). This study believes that the differential investment behaviours exhibited by the sample farm households over the soil conservation and erosion control practices may have resulted from differences in their socioeconomic and agronomic circumstances which are hereby analyzed.
Multivariate probit model results of determinants of farm level investments behaviours in soil conservation and erosion control practices Southast Nigeria: The results of the multivariate probit model estimated through an iterative maximum likelihood procedure are presented in table 5. The likelihood ratio test based on the log-likelihood value of the multivariate model indicates that the model, as specified, explained significant non-zero variations in the factors that determine farm-level investment behaviours in the soil conservation and erosion control practices. Parameter estimates for the model were evaluated at $10 \%, 5 \%$ and $1 \%$ levels of significance.

Thirteen out of eighteen parameters included in the multivariate probit specification were significant determinants of farm-level investment behaviours in the three soil conservation and erosion control practices evaluated in this study. These parameters are related to the farm households' socioeconomic circumstances, including age of the farm household head, farm size above sample mean farm size of 0.7 ha, farm income, non-farm incomes, level of formal education of farm household head, farmers' ownership and control over cultivated lands, length of land lease, membership and participation in farmers' associations and other community social groups, contacts with soil conservation and erosion control extension workers, farmers' knowledge of the introduced conservation practices, gender; and the agronomic and biophysical features of the farm household fields, including the slope and toposequence location of the farm fields. The erosivity of farmers' land use and nearness of farmers' farm fields to farm households' residence significantly influenced farmers' application of mulch and cover crops, but were not important determinants of farmers' application of hedgerows of leguminous plant species to control soil loss in the area. Table 5 also shows that although, factors such as farmers' access to credit and family size had positive relationships with farmers' investment decisions, they were not important determinants of farmers' investments in the soil conservation and erosion control practices. Farmers' fallow practices discouraged farm level investment in the three soil conservation and erosion control practices, because it was an unavailable alternative choice in the studied communities, where virtually all the arable and marginal lands have been put into agricultural and non-agricultural uses. 
Table 5 shows that farm households whose farm sizes are above the sample mean farm size of 0.7 ha (Table 2) invested more significantly in the three soil conservation and erosion control practices; while farmers operating land holdings below the sample mean may have viewed the establishment of the conservation technologies especially alley cropping as competing with their food crops under the land scarcity situations in the sampled communities. They may have lacked sufficient land for experimenting with the recommended conservation practices for investment decisions to occur. This may have accounted for their lower likelihood to invest in the technologies. The above finding raises a cautionary note to the conventionally held views to target conservation technologies to areas with high land use and demographic pressures (Ehui, etal; 1992; Carter, 1993; Onu, 2006). Farmers in the studied erosionprone communities are perhaps more likely to have higher labour productivity from investments in other conservation and resource management technology alternatives such as in organic manure and chemical fertilizers.

Contrarily, farmers below the sample mean age of 44 years have greater probabilities of investing in the recommended conservation practices. This implies that younger farmers exposed to improved conservation and erosion control practices will have increasing investment likelihood in the technologies, other factors being equal, as they gain more knowledge of the benefits of their investments and have the opportunity to adjust their productive resources overtime. This may be because younger farmers are more flexible, have longer planning horizon and tend to have lower risk aversion tendencies than their older counterparts (Onu, 2006). These younger progressive farmers should be the primary targets of extension information regarding farm innovations, especially soil conservation and erosion control practices.

Table 5 also shows that literate farmers are less sceptical of the soil conservation and erosion control practices, as investments increased significantly with increase in farmers' level of formal education. Similar findings have been recorded by Onu (2006).

Farmers' ownership and control over cultivated lands positively and significantly influenced farmers' investment decisions in the recommended soil conservation and erosion control practices. The forms of land ownership as used by this study need clarification. Subsistence farmers in Southeast Nigeria have traditional ownership rights to farmland either through inheritance or as part of their communal holdings, but control over land use and allocation differ. Four farms of land ownership based on degree of control over allocation and usage were common in the studied communities, namely, purchased/ received as gift, divided inheritance, undivided and secondary access. Land held under divided inheritance means that land is divided among the heirs, with each having full control over own parcel of land. Land held under undivided inheritance means that land is passed on to heirs collectively, with the result that no person has absolute control over any part of the land. Secondary access generally implies that land is obtained through pledge, loan or rental agreement. In this study, investments in the soil conservation and erosion control practices increased as private ownership and individual control over land increased, with land under divided inheritance and land purchased or received as gifts constituting more favourable conditions for conservation applications.

Length of land lease positively and significantly influenced farmers' soil conservation and erosion control practices investment decisions. Table 5 shows that as the length of land lease for rented lands increased, farmers applied more of the conservation technologies on their rented lands. This must have resulted from the fact that shortened lease periods do not allow farmers to recapture the costs of their investments in most of the conservation practices, which entails insecurity and uncertainty over use of rented lands. This is not surprising since tangible benefits from some of the conservation practices for example, alley cropping trees may not become available for the first 2-3 years, and once established, trees have to be well maintained for at least 5-10 years in order to derive long-term benefits from it (Onu, 2006). If the potential benefits of the practices can be realized and guaranteed through lengthened lease periods, the incentive for investment in the practices becomes brighter for renters. 
Agric. Biol. J. N. Am., 2013, 4(4): 441-458

Table 5: Result of the multivariate probit estimate of determinants of farmers' investment behaviours in soil conservation and erosion control practices in Southeast Nigeria.

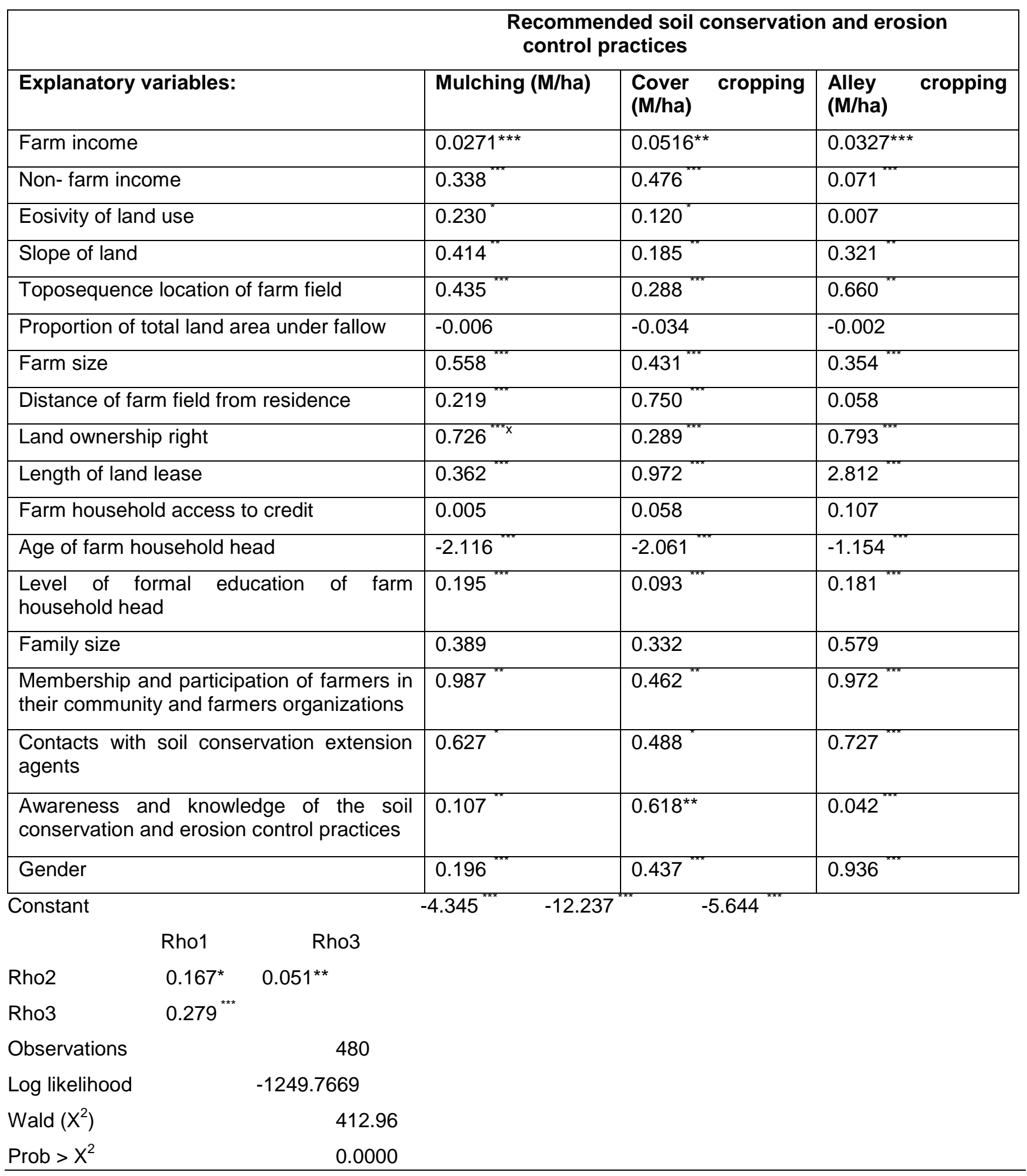

${ }^{*},{ }^{* *},{ }^{* *}$ significant at $10 \%, 5 \%$ and $1 \%$ respectively 
Agric. Biol. J. N. Am., 2013, 4(4): 441-458

Table 6: Studies on soil conservation and erosion control by mulching.

\begin{tabular}{|c|c|c|c|}
\hline BENEFICIAL EFFECT & AUTHOR(S) & LOCATION & KIND OF MULCH \\
\hline $\begin{array}{l}\text { Reduction of splash effect of rain } \\
\text { Decrease of runoff velocity } \\
\text { Reduction of soil loss }\end{array}$ & $\begin{array}{l}\text { Lal 1976a } \\
\text { Odunze } 2002 \\
\text { Adekalu et al, } 2006 \\
\text { Salako et al, } 2006\end{array}$ & $\begin{array}{l}\text { Ibadan } \\
\text { Zaira } \\
\text { SW Nigeria } \\
\text { Ibadan }\end{array}$ & $\begin{array}{l}\text { Straw of Oryza sativa } \\
\text { Staw mulch } \\
\text { Leavea of Phylolostachys bambusoides } \\
\text { Residues of zea mays }\end{array}$ \\
\hline $\begin{array}{l}\text { Decrease of soil bulk density, } \\
\text { penetration resistance }\end{array}$ & $\begin{array}{l}\text { Lal } 1978 \\
\text { Hulugalle et al, } 1987 \\
\text { Lal } 2000\end{array}$ & $\begin{array}{l}\text { lbadan } \\
\text { Onne } \\
\text { lbadan }\end{array}$ & $\begin{array}{l}\text { Straw mulch } \\
\text { Eupatorium odoratum } \\
\text { Straw of } O \text {. sativa }\end{array}$ \\
\hline $\begin{array}{l}\text { Increase of size + stability of soill } \\
\text { aggregates }\end{array}$ & Oyedele et al, 1999 & SW Nigeria & $?$ \\
\hline $\begin{array}{l}\text { Increase of infiltration capacity, } \\
\text { hydraulic conductivity }\end{array}$ & $\begin{array}{l}\text { Lal } 1975 \\
\text { Ogban et al, } 2001 \\
\text { Chiroma et al, } 2004\end{array}$ & $\begin{array}{l}\text { Ibadan } \\
\text { Uyo } \\
\text { maiduguri }\end{array}$ & $\begin{array}{l}\text { ? } \\
\text { grass } \\
\text { wood shavings }\end{array}$ \\
\hline $\begin{array}{l}\text { Increase in soil moisture } \\
\text { Decrease of soil temperature }\end{array}$ & $\begin{array}{l}\text { Lal } 1978 \mathrm{a} \\
\text { Lawson and Lal } 1980 \\
\text { Lal } 2000 \\
\text { Agele et al, } 2000 \\
\text { Chiroma et al, } 2005 \mathrm{~b}\end{array}$ & $\begin{array}{l}\text { Ibadan } \\
\text { lbadan } \\
\text { Ibadan } \\
\text { Akure } \\
\text { Maiduguri }\end{array}$ & $\begin{array}{l}\text { Straw mulch } \\
\text { Straw of O. sativa } \\
\text { Straw of O. sativa } \\
\text { ? } \\
\text { Straw of Triticum ssp. }\end{array}$ \\
\hline $\begin{array}{l}\text { Increase of activity and species } \\
\text { diversity of soil flora and fauna }\end{array}$ & $\begin{array}{l}\text { Lal } 1975 \\
\text { Salau et al } 1992 \\
\text { Tian et al, } 1997\end{array}$ & $\begin{array}{l}\text { Ibadan } \\
\text { lbadan } \\
\text { Ibadan }\end{array}$ & $\begin{array}{l}\text { ? } \\
\text { straw of Pennisentum purpureum, perforated plastic, wood } \\
\text { shavings } \\
\text { Prunings of Dactyladenia barteri, Gliricidia sepium, leucaena } \\
\text { Leucocephala, stover of } Z \text {. Mays, straw of } O \text {. sativa }\end{array}$ \\
\hline Suppression of weeds & $\begin{array}{l}\text { Lal } 1975 \\
\text { Lawson and Lal } 1980\end{array}$ & $\begin{array}{l}\text { Ibadan } \\
\text { lbadan }\end{array}$ & $\begin{array}{l}\text { Straw of } O . \text { sativa } \\
\text { Strats }\end{array}$ \\
\hline $\begin{array}{l}\text { Increase of organic matter }+ \\
\text { nutrient content }\end{array}$ & $\begin{array}{l}\text { Juo and Lal } 1977 \\
\text { Maurya } 1988 \\
\text { Mbagwu } 1991 \\
\text { Tian et al } 1993 \\
\text { Vanlauwe et al, } 1996 \\
\text { Chiroma et al, 2006a }\end{array}$ & $\begin{array}{l}\text { Ibadan } \\
\text { Bakura } \\
\text { Nsukka } \\
\text { Ibadan } \\
\text { Ibadan } \\
\text { Maiduguri }\end{array}$ & $\begin{array}{l}\text { Stove of } Z \text {. mays } \\
\text { Residures of } Z \text {. mays, Triticum ssp. } \\
\text { Straw of } P \text {. purpureum } \\
\text { Prunings of Dactyladenia barteri, Gliricidia sepium, Leucaena } \\
\text { leucocephalab, stover of } Z \text {. mays, Straw of O. sativa } \\
\text { Root + leaf residures of } L \text {. leucocephala, D. barteri, Flemingia } \\
\text { macrophylla } \\
\text { Wood shavings }\end{array}$ \\
\hline Increase of crop yield & $\begin{array}{l}\text { Lal } 1978 \\
\text { Okibgo } 1979 \\
\text { Lawson and Lal } 1980 \\
\text { Maurya and Lal 1980b } \\
\text { Maurya and Lal } 1981 \\
\text { Maduakor et al. } 1984 \\
\text { Hulugalle et al, } 1985 \\
\text { Hulugalle et al, } 1987 \\
\text { Mbagwu } 1991 \\
\text { Salau et al, } 1992 \\
\text { Osiru and Hahn } 1994 \\
\text { Lal 1995b } \\
\text { Olasantan 1999 } \\
\text { lbewiro et al, 2000 } \\
\text { Lai 2000 } \\
\text { Mbagwu 2000 } \\
\text { Kolawole et al, 2004 } \\
\text { Chiroma et al, 2006b } \\
\text { Anikwe et al 2007a }\end{array}$ & $\begin{array}{l}\text { Ibadan } \\
\text { Nsukka } \\
\text { lbadan } \\
\text { lbadan } \\
\text { lbadan } \\
\text { Onne } \\
\text { Onne } \\
\text { Onne } \\
\text { Nsukka ibadan } \\
\text { lbadan } \\
\text { lbadan } \\
\text { lia-Orangun } \\
\text { lbadan } \\
\\
\text { lbadan } \\
\text { Nsukka } \\
\text { lbadan } \\
\text { Maiduguri } \\
\text { Enugu }\end{array}$ & $\begin{array}{l}\text { Straw of } O \text {. sativa } \\
\text { Plant residues of? } \\
\text { Straw of } O \text {. sativa } \\
\text { Straw of } O \text {. sativa } \\
\text { Straw of } O \text {. sativa, polythene } \\
\text { Palm fronds } \\
? \\
\text { E. odoratum } \\
\text { Straw of } P \text {. purpureum } \\
\text { p. purpureum, perforated plastic, wood shavings } \\
\text { polyethylene plastic, straw of } O \text {. sativa } \\
\text { Residues of } Z \text {. mays } \\
\text { shoots of } E \text {. odoratum } \\
\text { Residues of } M \text {. prurienns var, utilis, lablab purpureus, leaves+ } \\
\text { rhizomes of imperata cylindrical } \\
\text { Straw of } O \text {. sativa } \\
\text { ? } \\
P \text {. phaseoloides } \\
\text { wood shavings } \\
\text { plastic- film mulch }\end{array}$ \\
\hline $\begin{array}{l}\text { Constraints } \\
\text { Not sufficient mulching material } \\
\text { Crop residues used as animal } \\
\text { fodder, firewoods, construction } \\
\text { materials } \\
\text { Residues reduced by termites } \\
\text { and cattle } \\
\text { Residues destroyed by burning }\end{array}$ & $\begin{array}{l}\text { Kayambo and Lal } 1993 \\
\text { Kirchhof and Odunze } 2003 \\
\text { Maurya } 1988 \\
\text { Okigbo } 1977\end{array}$ & $\begin{array}{l}\text { N Nigeria } \\
\text { N Nigeria } \\
\text { N Nigeria } \\
\text { Nigeria }\end{array}$ & $\begin{array}{l}- \\
- \\
-\end{array}$ \\
\hline
\end{tabular}

Source: Junge, et.al; 2008. Research Report on Soil Conservation in Nigeria: Past and present on-station and on-farm initiatives. Soil and Water

Conservation Society, Ankeny, lowa, USA. 
Agric. Biol. J. N. Am., 2013, 4(4): 441-458

Table 7: studies on soil conservation and erosion control by cover cropping

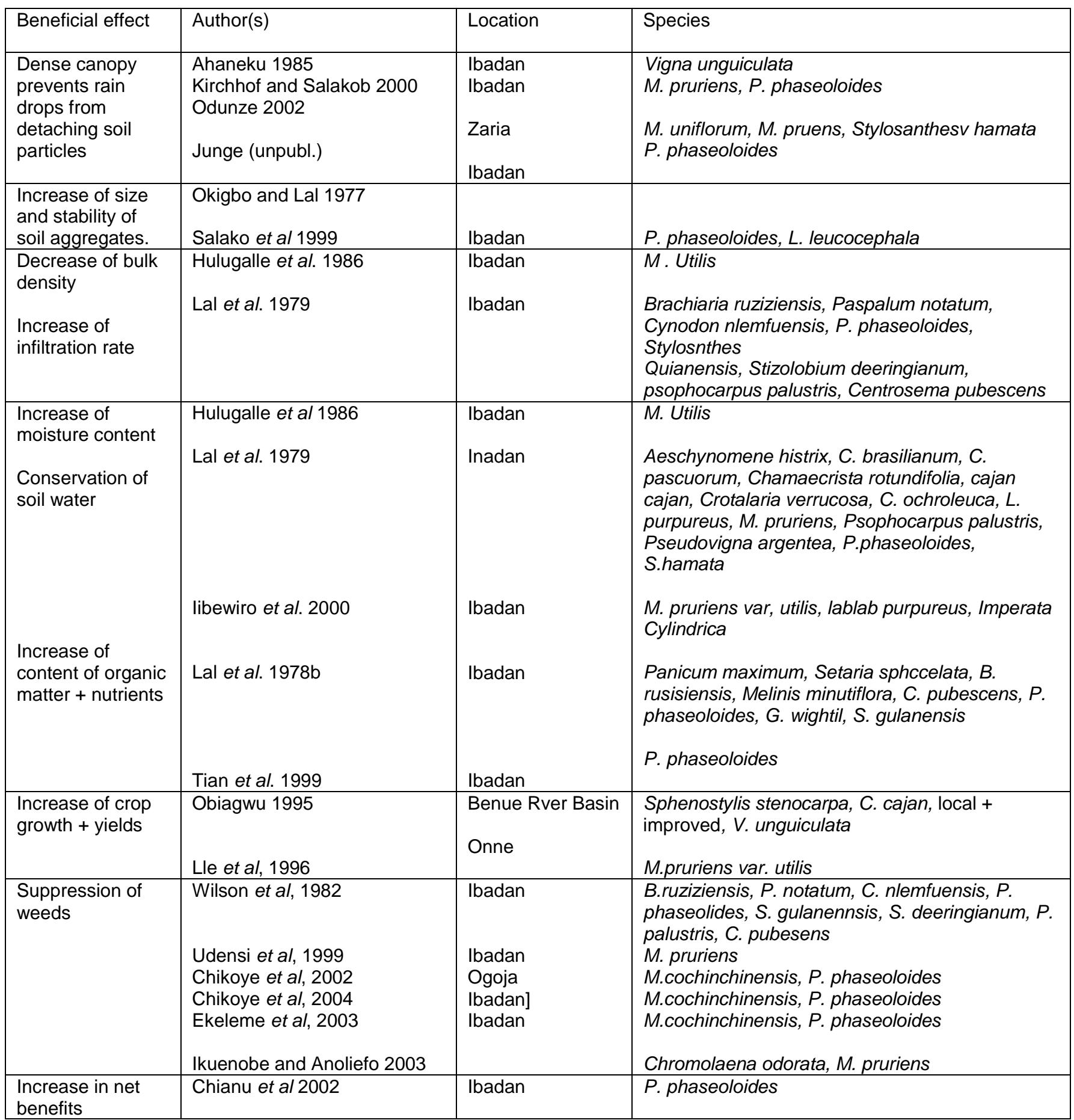

Source: Junge, et.al; 2008. Research Report on Soil Conservation in Nigeria: Past and present on-station and onfarm initiatives. Soil and Water Conservation Society, Ankeny, lowa, USA. 
Agric. Biol. J. N. Am., 2013, 4(4): 441-458

Table 8: Studies on soil conservation and erosion control by alley cropping

\begin{tabular}{|c|c|c|c|}
\hline Beneficial effect & Author(s) & Location & Species \\
\hline $\begin{array}{l}\text { Reduction of soil } \\
\text { loss }\end{array}$ & $\begin{array}{l}\text { Lal } 1989 \\
\text { Kang and Ghuman } 1991 \\
\text { Nair et al. } 1991\end{array}$ & $\begin{array}{l}\text { Ibadan } \\
\text { Ibadan }\end{array}$ & $\begin{array}{l}\text { L. leucocephala, G. sepium } \\
\text { L. leucocephala, G. sepium } \\
\text { (review) }\end{array}$ \\
\hline $\begin{array}{l}\text { Improvement of } \\
\text { soil structure, } \\
\text { infiltration rate }\end{array}$ & $\begin{array}{l}\text { Lal } 1989 \\
\text { Kang et al. } 1995\end{array}$ & Ibadan & L. leucocephala, G. sepium \\
\hline $\begin{array}{l}\text { Increase of } \\
\text { faunal activity }\end{array}$ & $\begin{array}{l}\text { Kang et al. } 1995 \\
\text { Hauser } 1992 \\
\text { Hauser et al. } 1998 \\
\text { Asawalam } 2006\end{array}$ & $\begin{array}{l}\text { Ibadan } \\
\text { Ibadan } \\
\text { Umudike }\end{array}$ & $\begin{array}{l}\text { L. leucocephala } \\
\text { L. leucocephala, S. siamea, D. barteri } \\
\text { L. leucocephala }\end{array}$ \\
\hline $\begin{array}{l}\text { Improvement of } \\
\text { nutrient recycling }\end{array}$ & $\begin{array}{l}\text { Raintree } 1980 \\
\text { Sanginga et al. } 1989 \\
\text { Hauser } 1990 \\
\text { Atayese et al. } 1993 \\
\text { Mulongoy et al. } 1993 \\
\text { Vanlauwe et al. } 1996 \\
\text { Kang et al. } 1999 \mathrm{a} \\
\text { Kang et al. } 1999 \mathrm{~b} \\
\text { Okogun et al. } 2000 \\
\text { Sanginga and mulangoy } 1995 \\
\text { Vanlauwe et al. } 2001 \\
\text { Vanlauwe et al. } 2005 \mathrm{a} \\
\text { Vanlauwe et al. } 2005 \mathrm{~b}\end{array}$ & $\begin{array}{l}\text { Fashola, Ibadan } \\
\text { Ibadan } \\
\text { Ibadan } \\
\text { Ibadan, Onne, Ise-Ekiti, } \\
\text { Boinu-Banga } \\
\text { Ibadan } \\
\text { Ibadan } \\
\text { Ibadan } \\
\text { Ibadan } \\
\text { Ibadan } \\
\text { Ibadan } \\
\text { Ibadan } \\
\text { WAfrica }\end{array}$ & $\begin{array}{l}\text { (review) } \\
\text { L. leucocephala } \\
\text { L. leucocephala } \\
\text { S. siamea, G. sepium, L. leucocephala } \\
\text { P. maximum, L. leucocephala, G. sepium, D. } \\
\text { barteri } \\
\text { L. leucocephala, D. barteri, F. macrophylla } \\
\text { G. sepium, ,L. leucocephala } \\
\text { G. sepium, L. leucocephala, } \\
\text { Alchornea cordifolia, D. barteri } \\
\text { Albizia lebbeck, S. corymbosato, S. siamea, L. } \\
\text { leucocephala, G. sepium } \\
\text { S. siamea, L. leucocephala } \\
\text { S. siamea, L. leucocephala, G. sepium } \\
\text { S. siamea, L. leucocephala, G. sepium } \\
\text { (review) }\end{array}$ \\
\hline $\begin{array}{l}\text { Maintenance of } \\
\text { organic matter }\end{array}$ & Mulongoy et al. 1993 & $\begin{array}{l}\text { Ibadan, Onne, Ise-Ekiti, } \\
\text { Boinu-Banga }\end{array}$ & $\begin{array}{l}\text { P. maximum, L. leucocephala, G. sepium, D. } \\
\text { barteri }\end{array}$ \\
\hline $\begin{array}{l}\text { Increase of crop } \\
\text { yield }\end{array}$ & $\begin{array}{l}\text { Siwa et al, } 1991 \\
\text { Osinubi and kang 1987a }\end{array}$ & $\begin{array}{l}\text { Ibadan } \\
\text { Ajaawa, Zakibiam }\end{array}$ & $\begin{array}{l}\text { L. leucocephala, A. barteri } \\
\text { L. leucocephala }\end{array}$ \\
\hline Control of weed & $\begin{array}{l}\text { Osinubi and kang 1987b } \\
\text { Yamoah et al,1986 }\end{array}$ & $\begin{array}{l}\text { Alabata } \\
\text { lbadan }\end{array}$ & $\begin{array}{l}\text { L. leucocephala, G. sepium } \\
\text { Cassia siamea, F. congesta, G. sepium }\end{array}$ \\
\hline $\begin{array}{l}\text { Increase of net } \\
\text { income }\end{array}$ & Chianu et al, 2002 & Ibadan & L. leucocephala, \\
\hline $\begin{array}{l}\text { Constraints } \\
\text { Lack of } \\
\text { synchronization } \\
\text { between crop N } \\
\text { demand and N } \\
\text { supply of } \\
\text { prunings } \\
\text { Competition of } \\
\text { shrubs, trees } \\
\text { with alley crops } \\
\text { No significant } \\
\text { effect of } \\
\text { prunings on } \\
\text { organic carbon }\end{array}$ & $\begin{array}{l}\text { Sanginga and Mulangoy } 1995 \\
\text { Smucker et al, } 1995 \\
\text { Iwuafor and Kumar } 1995\end{array}$ & $\begin{array}{l}\text { Ibadan } \\
\text { Ibadan } \\
\text { Samaru }\end{array}$ & $\begin{array}{l}\text { S. siamea, L. leucocephala, D. barteri, F. } \\
\text { macrophylla } \\
\text { L. leucocephala } \\
\text { L. leucocephala }\end{array}$ \\
\hline
\end{tabular}

Source: Junge, et.al.2008. A Research Report on Soil and Water Conservation in Nigeria: Past and present on station and on-farm initiatives. Soil and Water Conservation Society. Ankeny, lowa, USA 
The positive and significant relationship between membership in farmers' associations and investment in conservation practices implies that the more social organizations the farmers belong to and participate in their activities, the more likelihood of their predisposition to invest in farm technologies.

The exposure of farm families to the soil conservation and erosion control extension services information was very important in influencing farmers' investment decisions. The probabilities increased with increasing extension activities in the studied communities (Table 5). Increased household exposure (awareness and knowledge) to extension programmes through multiple extension agent visits and information dissemination, as well as technical support to farmers greatly increased farmers' knowledge gains of the available conservation technologies and their potential benefits, and triggered the soil conservation investment decisions to be taken by the farmers.

Farm income as a liquidity source as well as nonfarm income as a complementary liquidity source for hiring labour and buying conservation input materials exerted a positive significant effects on farmers' investment behaviours over the conservation practices. The situation may have been a result of the weak and undeveloped formal and informal farm credit market situations in the Southeast Nigeria, where farmers have highly limited access to credit (Farmers' access to credit $=0.084$ proportion, Table 2).

The positive and significant relationship between gender and the farmers' conservation investment behaviours in table 5 implies that the male-headed farm families invested more in soil conservation and erosion control practices than the female-headed farm households. This result is collaborated by the findings from earlier studies. For example, Fabiyi, et.al, (1991) and Onu (2006) found that in Southwest and in Imo State of Nigeria respectively, men farmers applied more alley cropping practices compared to women farmers. This situation may have resulted from the differential access to and control over land use rights between men and women farmers in Southeast Nigeria. Women in Southeast Nigeria are rarely allocators of land use rights; even their right to use land generally comes through men, either from a husband as a part of his holdings or from other male family members. This situation may have accounted for the observed lower likelihood of investment in the soil conservation and erosion control practices by women in this study.
Farmers applied more conservation treatments to their holdings at upper slopes where erosion is most severe (Table 5), which coincidentally are where they grow cowpea, maize and their other annuals in the sampled communities. This finding conforms with the a priori expectation that the greater the steepness of the slope on a toposequence location of farm fields, the greater the need for the farmers to invest in soil protection; as this condition tends to exacerbate the erosivity of the land use and accelerate soil loss. The observed soil conservation investment behaviours reflects farmers' indigenous knowledge system and practices in the sampled communities of placing their sloppy and floppy farm fields under woodlots as found in hedgerows, and mulch and cover crops with annual crops respectively.

Table 5 also shows that the more erosive forms of land use (high $C$-values) and nearness of farm fields to farm household residence (compound fields) particularly those cropped with annual crops received more conservation applications with respect to mulch and cover crops. Contrarily, there was no significant relationship between erosive forms of land use, nearness of farm fields to farmers' residence and application of alley cropping practices. The significant compound-distance field conservation treatment stereotype with mulch and cover crops may have resulted from farmers' conscious attempt to save travel/ transaction/conveyance costs, which may be relatively inconsequential in the establishment of alleys.

Contrary to a priori expectation, family size (as well as family size above the sample mean size of nine members) exerted insignificant influence on farmers' investment behaviours over the recommended conservation practices. This may have resulted from the fact that subsistence farm households are resource poor, and that larger family sizes may not, in real terms, contribute significantly in increasing the resource pool of the farm family, especially if some family members (i.e. School-age children) are not fulltime farm workers (Polson and Spencer, 1991). In the studied communities, major decisions are made by the heads of the household, while individual family members have very limited input in farm innovation investment decisions.

Table 5 shows that farmers' access to formal and informal credits was inconsequential in the conservation investment behaviours of farm households in Southeast Nigeria. This may have resulted from the fact that the credit market for agricultural production is highly under developed in 
Nigeria generally and especially in the Southeast region.

Conclusions and Policy implication: This study was based on micro-level analysis of the determinants of investment behaviours in soil conservation and erosion control practices in Southeast Nigeria. The multivariate probit econometric analysis used in the study showed that younger farmers, cultivating at least 0.7 ha of land, over which they have control in terms of allocation and usage had higher probabilities of investing in soil conservation and erosion control measures compared to the older farmers. The finding suggests that younger farmers are more likely to accept the risks associated with the application of soil conservation and erosion control practices, and should be the target of soil conservation and erosion control extension programme in Southeast Nigeria.

The results of the analysis confirm that the toposequence location of farmers' farm fields, their slope and the erosivity of farmers' land use were the biophysical and agronomic conditions that interact with the high and variable rainfall conditions in the Southeast Nigeria that results to massive soil loss; which defined and heightened the need for soil conservation and erosion control applications. The age and level of formal education of the farm household head, farm size, farm and non-farm incomes, ownership and control over cultivated lands, length of land lease, membership and participation in farmers' community social organizations, contact with soil conservation and erosion control extension workers, knowledge of the recommended conservation practices and gender determined farmlevel investments in soil conservation and erosion control practices in Southeast Nigeria. Soil conservation and erosion control extension programmes in Southeast Nigeria should be reformulated in consonance with these factors for greater effectiveness.

The roles of extension activities were very crucial in conservation investment decisions of farm households. Benefits from extension activities, therefore, would be maximized by targeting conservation extension activities on farmers' groups and associations, since farmers' membership and participation in such group activities also significantly influenced their exposure behaviours and investment decisions.

Since non-farm income as a liquidity source for hiring labour and buying conservation input materials exerted significant positive effects in farmers' conservation investment decisions. The extension programmes should also be reformulated to promote projects aimed at developing non-farm and off-farm enterprises in the ecologically vulnerable areas of Southeast Nigeria.

The limited land lease period ( $<1.20$ years) increased farmers' risk of appropriation of their investments in conservation practices, as it highlights insecurity and uncertainty over application of the technologies on rented lands, especially when the costs of the conservation innovations are considered. A system of cost-sharing through multi-year-written leases between land owners and operators are needed in order that renters can recapture the benefits generated by their investments in conservation practices in Southeast Nigeria.

\section{REFERENCES}

Belderbos, R.; M. Carree, B. Diederen, B. Lokshin, and R. Veugelers. 2004. Heterogeneity in R \& D cooperation strategies. International Journal of Industrial Organization 22: $1237-1263$.

Binswanger, H.P. 1986. Risk aversion, collateral requirements and the market for credit and insurance in rural areas. In: Crop Insurance for Agricultural Development. Hazell, P; Pomerada, C. and Valdes, A. (eds.) 25-27.

Cappellari, I. and S. P. Jenkins. 2003. Multivariate probit regression using simulated maximum likelihood. The Stata journal 3: $278-294$.

Carter, J 1995. Alley Farming: have resource poor farmers benefited? Natural resource perspectives $3: 1-4$.

Dvorak,K.A. 1996. Adoption potential of alley cropping final project report. $R C M B$ research bulletin no. 23. IITA, Ibadan, Nigeria.

Eboh, E. C. and J. I. Lemchi. 1994. Population pressure and indigenous land tenure in Eastern Nigeria:Implications for land tilting. Journal of Rural Development and Administration. 26(3): 77 - 82.

Egboka, B. 2004. Gully erosion in Alaigbo. Osundu Newsletters 4.

http://www.sound.com/abec/erosionindex.htm.

Ehrenstein, O. 2002. Crop residue mulching in tropical and semi-tropical countries: An evaluation of residue and other technologies implications. Soil and Tillage Research 67:115 - 133.

Ehui, S.K. and Pender, J. 2005. Resource degradation, Low agricultural productivity and poverty in subsaharan Africa: Pathways out of the spiril. Agricultural Economics 32(1): $225-242$. 
Ehui, S.K., Kang, B.T. and Spencer, \& S.C. 1992. Economic analysis of soil erosion effects in alley cropping, no-till and bush fallow system in south western Nigeria. In: Diversity, Farmer knowledge and sustainability. Moock, J.L. and Rhoades, R.E. (eds). Cornel University press, Ithaca, New York. $18-24$.

Eswaram, H., R. Lal and P. F. Reich. 2001. Land degradation: an overview. In Response to Land Degradation, eds. E. M. Bridges, I. D. Hannam, L. R. Oldeman, F. W. T. Pening de Vries, S.J. Scherr, and S. Sompatpanit(eds.). Proceedings of the $2^{\text {nd }}$. International Conference on land degradation and Desertification, Khon Kaen, January 1999. New Delhi: Oxford Press.

Fibiyi, Y.L., Idowu, E.O and Oguntade, A.E., 1991. Land tenure and management constraints to the adoption of alley farming by women in Oyo State of Nigeria. Nigerian Agricultural Extension Journal. 6 (12): 40 46.

Fournier, F., 1967. Research on soil erosion and soil conservation in Africa. African Soils. 12: 52-96.

Golob, T. F. and A. C. Regan. 2002. Trucking industry adoption of information technology: a multivariate discrete choice model. Transportation Research Part $C$ 10: $2005-228$.

Greenland, D.J. and Lal, R. 1977. Soil conservation and management in the humid tropics. Willey Press, London.

Hansen, D.O., Erbough, M.J., and Napier, T.L., 1987. Factors related to the adoption of soil conservation practices in the Dominican Republic. Journal of soil and water conservation 45 (5): $367-369$.

Hassan, R. M. 1996. Planting strategies of maize farmers in Kenya: a simultaneous equations analysis in the presence of discrete dependent variables. Agricultural Economic 15: 137 - 149.

Igbokwe, J. I. 2004. Gully erosion mapping / monitoring in parts of South-Eastern Nigeria. Paper presented at the National workshop on satellite remote sensing and GIS: a solution to sustainablenationaldevelopment challenges. Abuja. June, 15 - 17.

Igwe, C.A., 1999. Land use and soil conservation strategies for potentially high erodible soils of central eastern Nigeria. Land Degradation and Development 10: $425-434$

Junge, B; Abaidoo, R., Chickoye, D. Stahr, K., and Lal, R. 2008. Research Report on Soil Conservationin Nigeria: Past and present on-station and on-farm initiatives. Soil and water conservation society, Ankeny, lowa, USA.

Kang, B.T. Raynolds L, Atthkrah, A.A., 1990. Alley farming. Advanced Agronomy Journal. 43:315 - 359.
Kayombo, B. and Mrema, G.C. 1998. Soil conservation and sustainability of agricultural systems in subsaharan Africa. In: Soil Quality and Agricultural Sustainability. Lal, R(ed). Chelsea, Michigan: Sleeping Bear Press.

Lal, R. 1976.No-tillage effects on soil properties under different crops in western Nigeria. Soil Society of America Journal 40:762-768.

Lal, R. 1990. Soil erosion in the tropics: Principles and management. New York: McGraw-Hill

Lal, R. 1995. Tillage and mulching effects on maize yield for seventeen conservative seasons on tropical Ifisol. Journal of Sustainable Agriculture 5(4):79-93.

Lal, R. 2001. Soil degradation by Erosion. Land Degradation and Development 12: 519 - 539.

Lal, R., 1983. Erosion caused productivity decline in soils of the humid tropics. Soil Taxonomy News 5:4 - 11.

Lal, R.2008.Forward to the Research Report on Soil conservation in Nigeria: Past and present on-station and on-farm initiatives. Soil and Water Conservation Society, Ankeny, lowa, USA.

Lin. C. T. J., Jensen, K. L., and Yen, S.T. 2005. Awareness of food borne pathogens among US consumers. Food Quality and Preference 16: 401-412.

Mbagwu, J. S. C., Lal, L and Scot, T. W. 1984. Effects of desurfacing of Altisols and Ultisols in Southern Nigeria on crop performance. Soil Science Society of America Journal 48: 828 - 833.

Napier, T.L., Threan, C., Gove, A. and Gore, W., 1984. Factors affecting the adoption of conventional tillage practices in Ohio. Journal of soil and water conservation 39:205-208.

Newbery, D.M.G and Stiglitz, J.E. 1981. The theory of commodity price stabilization: A Study in the economics of risk. Clarendum Press, Oxford. 20 - 21.

Obiefuna, J. C. and L. C. Emebiri. 1996. Tree crop Farming Systems for erosion control in Southeastern Nigeria. In: Management and control of Erosion in Agricultural Practices: a Handbook. Njoku, J. E. and N. A. Ozara eds. Institute of Erosion Research, Federal University of Technology, Owerri, Nigeria. 7 - 21.

Onu, D. O. 2005. Determinants of farm - level soil conservation and erosion control adoption and utilization behaviours in the ecologically vulnerable areas of Imo State, Nigeria.Journal of Rural Development.24(4): 521 - 543.

Onu, D. O. 2006. Socioeconomic factors influencing farmers adoption of Alley farming Technologies under intensified agriculture in Imo Staten Nigeria. The Philippine Agricultural Scientist. 89(2): 521 - 543. 
Agric. Biol. J. N. Am., 2013, 4(4): 441-458

Polson, R., and Speneer, D.S.C. 1991. The technology adoption process in subsistence agriculture: The Case of Cassava in south western Nigeria. Agricultural Systems. 36:65 - 77.

Robinson, L.J.and Barry, P.J. 1987. Competitive Firm's Response to Risk. Macmillan Publishing Co., New York.
Tonye, J., Makemeze, C., and Titinwel, P. 1993. Implication of national land legislation and customary land and tree tenure on the adoption of alley farming. Agroforestry systems 22:153 - 160. 